\title{
PAMIĘĆ AUTOBIOGRAFICZNA W CZASACH CYFRYZACJI
}

Pytanie, jak widzimy siebie i innych na fotografiach, zawsze zajmowało uwagę teoretyków medium. Zarówno w tekstach fundujących kanon „myślenia fotografią" ${ }^{11}$ (Waltera Benjamina, Susan Sontag, Rolanda Barthes'a czy Johna Bergera), jak i w pracach nowszych (by wspomnieć tylko Nicolasa Mirzeoffa) odnajdujemy potrzebę przemyślenia sposobów pozostawiania wizualnego świadectwa życia oraz tworzenia własnego wizerunku - dla siebie i innych. Badaczy interesuje zarówno ontyczny, jak i epistemologiczny wymiar dokumentowania doświadczenia indywidualnej egzystencji oraz jego znaczenie dla kształtu pamięci zbiorowej. Pytanie o rejestrację indywidualnego doświadczenia życiowego w ujęciach teoretycznych formułowane jest różnorako. Może dotyczyć sposobów konstrukcji albumu rodzinnego (Marianne Hirsch), kwestii selfie, traktowanego jako „poszerzenie i wzmocnienie długiej tradycji autoportretu”2; działania ucieleśniającego wyobrażoną tożsamość, zakorzenionego w praktykach komunikacyjnych ${ }^{3}$. Istotą tych dyskusji jest postrzeganie siebie oraz innych, a także technologiczna możliwość obrazowania, doświadczania oraz społecznego dystrybuowania tych wyobrażeń.

W artykule przyglądam się fotografii z perspektywy narracyjnej, wykorzystując zyskujące na popularności od lat 70 . ubiegłego wieku pojęcie pamięci autobiograficznej. Sposoby „opisania (graphia) życia (bíos) jednostki, dokonane przez nią samą (auto)" ${ }^{4}$ interesują dzisiaj nie tylko literaturoznawców i historyków, lecz coraz częściej stanowią przedmiot badań psychologów, socjolo-

${ }^{1}$ Odwołuję się tu do określenia rozpropagowanego przez Victora Burgina, autora głośnej antologii tekstów pod tym właśnie tytułem. Redaktor zbioru ujmuje teorię fotografii jako „praktykę sygnifikacji”. Zob. Thinking Photography, red. V. Burgin, London 1982, s. 2.

${ }^{2}$ N. Mirzeoff, Jak zobaczyć świat, tłum. Ł. Zaremba, Warszawa 2016, s. 44.

${ }^{3}$ J. van Dijck, Mediated Memories in the Digital Age, Stanford, California, 2007, s. 118.

${ }^{4}$ M. Marszałek, Autobiografia, w: Modi memorandi. Leksykon kultury pamięci, red. M. Saryusz-Wolska, R. Traba, Warszawa 2014, s. 53. 
gów i teoretyków kultury5 . Pamięć autobiograficzna (mam tu na myśli sposób, w jaki jednostki rekonstruują wyobrażenie własnej przeszłości) pozwala zadać pytanie nie tylko o to, jak działają mózgowe systemy przechowywania wspomnień, ale przede wszystkim o to, jakie są relacje pamiętania do kulturowego ukształtowania obrazów przeszłości. Chodzi zatem o uwzględnienie tego, co i jak pamiętamy, ale też tego, jak treść wspomnień jest przekształcana za sprawą czynników społecznych, kulturowych oraz technologicznych. Pamięć autobiograficzna jest ujmowana jako proces oraz wypowiadana jako narracja (ustna, literacka, wizualna, obrazowo-tekstowa). Historyk psychologii Douwe Draaisma, wyjaśniając pojęcie, przywołuje porównanie zastosowane przez Philippe'a Lejeune'a, w którym pamięć zostaje nazwana podlegającym korekcie „brudnopisem własnego życia”" Zgodnie z koncepcjami psychologii nie mamy całkowitej władzy nad „poprawkami” wprowadzanymi do tego brudnopisu. Holenderski badacz pamięci pisze: „brudnopis podlega korekcie - to nie my piszemy na nowo nasze wspomnienia, ale jest to robione za nas" ${ }^{\prime \prime}$.

Jeśli porównamy pamięć do brudnopisu, to uznamy, że jest ona - by tak powiedzieć - „pisywalna”, a tym samym jest narracją. Ten narracyjny wymiar pamięci autobiograficznej zachęca, by w analizie fotografii jako nośnika pamięci wprowadzić kolejny termin: „tożsamości narracyjnej”. Przypomnijmy tylko, że ten termin rozpatrywać można w dwu, co najmniej, interpretacjach. W wersji socjologicznej Anthony'ego Giddensa jest refleksyjnym projektem samorozumienia jednostki w świecie ${ }^{8}$ pełnym ryzyka, by w fenomenologicznej refleksji Paula Ricoeura stać się dialektyczną relacją rozpoznawania siebie: wędrującą pomiędzy „niezmiennością idem - tego samego [du même], i ruchomej tożsamości ipse - tożsamości siebie [du soi]"9. W tekście wykorzystam tę drugą perspektywę, ze względu na znaczącą rolę pamięci w procesie rozpoznawania siebie w narracjach ${ }^{10}$.

Interesuje mnie zatem konstruowanie pamięci autobiograficznej za pomocą fotografii oraz jej odniesienie do indywidualnej tożsamości. Początkowo bowiem można fotografię uznać za nośnik i „wspomagacz” pamięci, by ostatecznie uznać, że staje się ona świadectwem życia jednostki i społecznie przedstawianym jego potwierdzeniem. Jak pisze Jolanta Brach-Czaina: „po-

${ }^{5}$ Wyczerpującą listę pozycji bibliograficznych poświęconych badaniu autobiografii dostarcza Magdalena Marszałek w haśle Autobiografia, zob. ibidem, s. 57-58.

${ }^{6}$ D. Draaisma, Księga zapominania, tłum. R. Pucek, Warszawa 2012, s. 22-23.

7 Ibidem, s. 23.

8 A. Giddens, Nowoczesność i tożsamość, tłum A. Szulżycka, Warszawa 2006, s. $104-108$.

9 P. Ricoeur, Drogi rozpoznania, tłum. J. Margański, Kraków 2004, s. 90.

10 Ibidem, s. 89. 
wszechny zwyczaj fotografowania się sprawia, że zdjęcia stały się głównym świadectwem faktu naszego życia i zapisem przemian, jakie $z$ upływem lat każdy przechodzi"11. Ma to swoje odzwierciedlenie, z jednej strony, w tym, że uporczywie dokumentujemy świat wokół nas, z drugiej - że kolekcjonujemy własne wizerunki. Chociaż zasadniczo tematem artykułu jest pamięć autobiograficzna, część omawianych realizacji wizualnych odnosi się do terminu szerszego - pamięci biograficznej, która nie musi już odnosić się do wspomnień podmiotu opowiadającego o sobie, ale dotyczyć tego, jak on/ona widzą i przekształcają obrazy innych. To poszerzenie przykładów, w mojej opinii, pozwala rozpoznać napięcie między Ricoeurowskim rozpoznawaniem tożsamości przez jednostkę i postrzeganiem jej przez innych.

Artykuł został podzielony na dwie części. Pierwsza ma charakter teoretyczny; przedstawiam w niej rodzaje opartych na fotografii badań nad pamięcią autobiograficzną oraz przybliżam koncepcje wyjaśniające działanie pamięci autobiograficznej. W drugiej-opierając się na realizacjach artystycznych (m.in. Nancy Burson, Krzysztofa Pruszkowskiego, Marka Lalko) oraz na codziennych praktykach fotografowania (m.in. selfie) i przetwarzania obrazów (w formie filmów poklatkowych) - zastanawiam się, czy możliwa jest wizualna autobiografia.

\section{O BADANIACH PAMIĘCI AUTOBIOGRAFICZNEJ}

\section{PERSPEKTYWA FUNKCJONALNA - WYKORZYSTANIE FOTOGRAFII W BADANIACH JAKOŚCIOWYCH}

Wyróżniłabym dwa sposoby obecności fotografii we współczesnych badaniach kulturowych nad pamięcią: pierwszy, funkcjonalny, związany jest $z$ wykorzystywaniem fotografii w badaniach jakościowych nad pamięcią, drugi - nazwijmy go refleksyjnym - prowadzi do rozważań o charakterze zapisu fotograficznego w czasie, a także do pytań o tożsamość sfotografowanych: jaką /jakiego siebie widzę?

W tej części tekstu przyjrzymy się funkcji fotografii we współczesnych badaniach jakościowych. Nietrudno dostrzec, że stanowi ona popularne narzędzie wspomagające $\mathrm{w}$ wielu metodach badawczych, wykorzystywanych w psychologii, socjologii i etnografii wizualnej czy badaniach kulturowych nad pamięcią ${ }^{12}$. Spośród wielu metod wymienić można tu (jako najściślej

11 J. Brach-Czaina, Błony umysłu, Warszawa 2003.

12 Zob. D. Harper, Co nowego widać?, tłum. Ł. Rogowski, w: Metody badań jakościowych, red. N.K. Denzin, Y.S. Lincoln, t. 2, Warszawa 2009, s. 153-174. 
odnoszące się do badań pamięci autobiograficznej) wywiady narracyjne na podstawie fotografii, foto-wywoływanie (photo elicitation) ${ }^{13}$, technikę esejów wizualnych ${ }^{14}$, visual storytelling ${ }^{15}$, techniki fototerapeutyczne ${ }^{16}$ czy metody oparte na sztuce ${ }^{17}$.

Zwłaszcza metody foto-wywoływania oraz rozmaite sposoby wykorzystania wywiadów i rozmów o fotografiach wydają się szczególnie efektywne w badaniu pamięci autobiograficznej. Piotr Jakub Fereński przypomina opisaną przez Douga Harpera klasyfikację badań. Pisze Fereński: „Studia prowadzone na podstawie foto-wywoływania koncentrują się w czterech obszarach badawczych: a) organizacji społecznej / klas społecznych / rodziny, b) wspólnotowości, c) tożsamości / biografii / autobiografii oraz d) kultury"18. Nas interesować będzie punkt trzeci: tożsamość / biografia / autobiografia. Najprościej mówiąc, metoda photo elicitation ma na celu wydobycie doświadczeń rozmówców w trakcie swobodnej rozmowy o fotografiach.

${ }^{13}$ Piotr Fereński proponuje takie właśnie tłumaczenie angielskiego terminu, zwracając uwagę na takie cechy słowa elicitation, jak: „aktywizacja, poruszanie, wydobywanie, ujawnianie". Odróżniam tę metodę od wywiadów na podstawie fotografii, ponieważ ma ona własną specyfikę procesu badawczego i przede wszystkim usytuowania metodologicznego. P.). Fereński, Rozmowy o fotografiach, „Przegląd Kulturoznawczy” 2012, 12(2), s. 155.

${ }^{14} \mathrm{~W}$ tym wypadku chodziłoby o te eseje wizualne, które odnoszą się do określenia własnej sytuacji autora.

15 Grupą ciekawych technik „wizualnego opowiadania” są sposoby budowania komunikatu wizualnego przez samych uczestników badania. W tej grupie uczestniczących (participatory) metod Richard Chalfen wyróżnia: metodę autofotograficzną, fotografię hermeneutykę, narracje wizualne, visual/digital storytelling, dzienniki wizualne (pictorial diaries), dokumentalne filmy biograficzne (bio-documentary films), społeczne filmy dokumentalne (socio-documentary films), wideo uczestniczące (participative video) i foto/wideoterapie (photo/video therapy). Zob. R. Chalfen, Differentiating Practices of Participatory Visual Media Production, w: The Sage Handbook of Visual Research Methods, red. E. Margolis, L. Pauwels, London 2011, s. 188.

16 Szczegółowe rozróżnienia pomiędzy poszczególnymi praktykami fototerapeutycznymi wprowadza Judy Weiser. Odróżnia ona „fotografoterapię”, opartą na technikach warsztatowych, od fotografii terapeutycznej, opartej głównie na interpretacji obrazów zastanych. Zob. J. Weiser, Using Personal Snapshots and Family Photographs as Therapy Tools: The "Why, What, and How" of PhotoTherapy Techniques, „PsicoArt" [online] 2010, 1, s. 2, $<$ https://phototherapytherapeuticphotography.files.wordpress.com/2014/10/weiser_psicoart_english_2010.pdf> [dostęp: 25 stycznia 2017].

${ }_{17} \mathrm{~W}$ kontekście artykułu szczególnie przydatne byłyby techniki określane przez Susan Finley jako „moja opowieść”. Zob. S. Finley, Badania posługujące się sztuka. Rewolucyjna pedagogika oparta na performansie, tłum. M. Podgórski, w: Metody badań jakościowych, s. $57-80$.

${ }^{18}$ Ibidem. 
Spójrzmy, jaki kształt powyższe metody przyjmują w psychologii. Fotografie pojawiają się tu (podobnie w gruncie rzeczy jak w innych dyscyplinach nauk, wykorzystujących zdjęcia) na dwu poziomach: opowiadania o gotowych obrazach, która to interpretacja odbywa się w trakcie rozmowy badanego $z$ badaczem oraz/lub poprzez realizację materiału fotograficznego przez samego badanego. Odczytywanie fotografii jest ściśle związane z procesami pamięciowymi. Chociaż Judy Weiser, jedna z twórczyń fototerapii, nazywa fotografie „zamrożonymi wspomnieniami, które możemy ująć w dłonie w milczącej nieruchomości [silent stillness]"19, to jest przekonana, że opowieść odbiorcy oparta jest na procesach i znaczeniach subiektywnych i związanych $z$ indywidualnymi doświadczeniami. Podkreśla także specyficzną relację, tworzoną pomiędzy konkretnym zdjęciem i odbiorcą. Fototerapeutka pisze: „faktyczne znaczenie każdego zdjęcia istnieje tylko jako nieobserwowalny, chociaż niekoniecznie przypadkowy, punkt przecięcia zmysłowo kodowanych skojarzeń, które pojawiają się wyłącznie w nieuchwytnym oddziaływaniu pomiędzy umysłem odbiorcy i tego konkretnego obrazu"20. Fotografie zatem są uznawane przez badaczy za środek prowadzący do uruchomienia sfery doświadczeń, skojarzeń i wspomnień indywidualnego odbiorcy.

Podawany przez Douwe Draaismę przykład zastosowania fotografii w terapiach uaktywniających pamięć osób starszych zdaje się potwierdzać obserwację Weiser. W Fabryce nostalgii autor opisuje terapie prowadzone z osobami cierpiącymi na lekką demencję w domu opieki „Herik” w holenderskim mieście Borger. Terapeuci korzystają ze zdigitalizowanych archiwów fotograficznych prowincji Drente, wyszukując w nich obrazy miejsc, w których wychowywali się pensjonariusze. Następnie prowadzą rozmowy o wybranych zdjęciach. Psycholog pisze o eksperymencie prowadzonym w grupie kobiet:

[...] kiedy na stole zostają rozłożone fotografie, ich twarze się ożywiają. Zaciekawione pochylają się do przodu. [...] Po zaprezentowaniu tych dwóch fotografii trudno uwierzyć, że ci sami ludzie jeszcze kwadrans wcześniej siedzieli w sali rekreacyjnej apatycznie pogrążeni w milczeniu. Opowiadają teraz o swojej młodości²1

Jednak Draaisma nie ma złudzeń. Chociaż, jak pisze, „demencja w połączeniu ze starymi fotografiami daje efekt przeniesienia" ${ }^{22}$, to ożywienie pamięci fotografiami jest chwilowe i - ze względu na charakter schorzenia - pozwala przenieść się tylko do jednego okresu - do dzieciństwa.

19 Weiser, Using Personal Snapshots..., s. 1.

${ }^{20}$ Ibidem, s. 2.

${ }^{21}$ D. Draaisma, Fabryka nostalgii. O fenomenie pamięci wieku dojrzałego, tłum. E. Jusewicz-Kalter, Wołowiec 2010, s. 128-130.

${ }^{22}$ Ibidem, s. 130. 
Wywiad na podstawie fotografii jest atrakcyjną metodą także dla socjologów wizualnych. John Grady podaje dwa rodzaje informacji, które dzięki fotografiom można uzyskać: zapis osobistego zaangażowania w scenę oraz bezosobowy zapis zdarzeń i zachowann ${ }^{23}$. Jest jednak świadomy tego, że interpretacja materiału wizualnego nie jest prosta i wymaga danych, których w samym obrazie nie znajdziemy - przede wszystkim narracji osoby, z którą prowadzona jest rozmowa.

Już z tego pobieżnego przeglądu metod angażujących fotografię wynika, że chociaż służą one odmiennym celom badawczym: poznaniu historii życia, aktywizacji pamięci czy uzyskaniu informacji o przeszłości, to funkcja zdjęć jest ujmowana podobnie - mają one „obudzić” pamięć i sferę skojarzeń, dzięki czemu dotrzemy do doświadczeń badanych. Coraz częściej do wspomagania pamięci autobiograficznej zaangażowane są współczesne technologie wizualne, takie jak SenseCam. Jest to zawieszana na szyi lub przypinana do ubrania kamera z szerokokątnym obiektywem, która rejestruje wszystko, co znajduje się przed nami. Psychologowie zachęcający do jej używania piszą:

Wydaje się, że SenseCam jest szczególnie dopasowana do terapii osób z uszkodzeniem pamięci lub zdolności poznawczych, ponieważ przechwytuje obrazy autonomicznie, umożliwiając pacjentom rejestrować ich doświadczenia bez świadomości, co oznacza, że osoba nosząca urządzenie może rzeczywiście uczestniczyć w wydarzeniu ${ }^{24}$.

Czy jednak sama rejestracja wydarzeń wystarczy, by pamięć autobiograficzna mogła być uaktywniona? Przyjrzymy się temu w kolejnej części artykułu.

PERSPEKTYWA REFLEKSYJNA - JAK DZIAEA PAMIĘĆ AUTOBIOGRAFICZNA I GDZIE W JEJ OBSZARZE JEST MIEJSCE DLA FOTOGRAFII?

Czas zatem przejść do drugiej z wymienionych na wstępie perspektyw oglądu fotografii autobiograficznej. W rozumieniu obrazu fotograficznego znajduję pęknięcie, które ujawniło się także, gdy przywoływałam poglądy Weiser

${ }^{23}$ J. Grady, Visual Research at the Crossroads, „Forum Qualitative Sozialforschung / Forum: Qualitative Social Research" 30 October 2008, 9(3) [online], <http://www.qualitativeresearch.net/index.php/fqs/article/viewArticle/1173/2618> [dostęp: 25 stycznia 2017].

24 S. Hodges, E. Berry, K. Wood, SenseCam: A wearable camera that stimulates and rehabilitates autobiographical memory, "Memory” [online], 2011, 7, s. 695, < http://www. tandfonline.com/doi/abs/10.1080/09658211.2011.605591> [dostęp: 25 stycznia 2017]. 
- pomiędzy nieruchomością obrazu i ruchem pamięci. Z jednej strony, nadal w języku potocznym do opisu działania fotografii stosuje się słowa odnoszące się do nieruchomości, takie jak: zamrożenie, unieruchomienie, utrwalenie, zdjęcie. Wspominany wcześniej historyk pamięci Draaisma notuje, że tradycyjne metafory pamięci, zorientowane na "konserwowanie, przechowywanie, rejestrację [...] są z natury konstrukcjami muzealnymi"25. Dołączająca do zespołu tych metafor po roku 1839 „pamięć fotograficzna” tę trwałość reprezentuje. $Z$ drugiej jednak strony, co można dostrzec w spisie kulturowych obrazów fotografii, sporządzonym przez literaturoznawcę i badacza mediów Berndta Stieglera ${ }^{26}$, metafory fotografii wcale nie opisują jednoznacznie nieruchomości obrazu, lecz odnoszą się do jej procesualnej percepcji. Wiele słów wybranych przez teoretyka ma formę czasownikową. Kulturowo zatem fotografia okazuje się bliższa stwarzaniu, wiwifikacji (ożywianiu) i wymazywaniu niż anglosaskiemu still (klatce, kadrowi, nieruchomości). W koncepcji Draaismy, z kolei, pamięć jest dynamiczna, ponieważ „zostaje zdominowana przez zapomnienie ${ }^{27}$, któremu przeciwstawiane są próby przypominania sobie tego, co zapomniane. Nawet słynny Barthes'owski noemat fotografii ça a été, jeśli uznamy go za zbieżny ze stroną punctum fotografii, okaże się zmienny i nietrwały ${ }^{28}$. Pewność istnienia przedmiotu na zdjęciu nie pokrywa się bowiem $z$ jego znaczeniem w pamięci.

To pęknięcie pomiędzy natarczywym obrazem przedmiotu i plastycznością jego rozpoznawania stanowi, w mojej opinii, fundament badania fotografii i jednocześnie sprawia, że fotografia uznawana jest za skuteczny nośnik pamięci autobiograficznej. Zanim przyjrzymy się fotografii, sięgnijmy do wyjaśnienia autora Księgi zapominania, tłumaczącego, jak działa pamięć autobiograficzna. Pozwolę sobie przywołać dłuższy fragment rozważań Holendra.

Przypominając sobie coś, tworzymy ślad neuronowy, a następnym razem, gdy pozornie przypominamy sobie to samo, w rzeczywistości zostaje zaktywowany ślad, który powstał najpóźniej. Wspomnienia, również te najstarsze, podróżują w miarę upływu czasu w naszej tkance mózgowej, lecz wciąż od nowa towarzyszą im kolejne kopie. Zgodnie $z$ tą teorią, gdy wracamy myślami do pierwszego wspomnienia, sprawiamy, że obwód neurologiczny naszej pamięci zamyka się w osobliwy sposób - najstarsze staje się na chwilę najnowszym, pierwsze ostatnim ${ }^{29}$.

25 Draaisma, Księga zapominania, s. 8.

26 B. Stiegler, Obrazy fotografii. Album metafor fotograficznych, tłum. J. Czudec, Kraków 2009.

27 Draaisma, Ksiega zapominania, s. 8.

28 R. Barthes, La chambre claire. Note sur la photographie, Paris 1980, s. 176.

29 Draaisma, Fabryka nostalgii, s. 6. 
Zatem, im częściej przypominamy sobie coś, tym bardziej owo wspomnienie się zmienia. Jak odnieść to neuropsychologiczne wyjaśnienie do działania fotografii? Wyobraźmy sobie, że patrzymy na fotografię pokazującą nasz dom w czasach, kiedy byliśmy dziećmi. Jeśli oglądaliśmy ów obraz jeszcze w dzieciństwie, to mogliśmy porównywać przedmioty na fotografii z tymi, które znaliśmy wtedy. Co jednak, jeśli zdjęcie obejrzymy po czasie? Jak w przypadku Lejeunowskiej metafory pamięci jako brudnopisu - patrząc na obraz po latach, „sami jesteśmy zdumieni tym, co w międzyczasie zostało zatarte i zapisane ${ }^{\prime \prime 0}$.

Obrazy zdarzeń, wywoływane z pamięci, ale też oglądane na fotografiach, mogą być źródłem zupełnie różnych narracji, ponieważ za każdym razem na nowo są rekonstruowane (to kompleks wspominanego wcześniej ça a été, które nie daje efektu trwałego. Barthes rozpoznał Matkę tylko w tamtym jednym momencie, by następnie ponownie ją utracić).

Tak też uważa Draaisma:

Nasze wspomnienia są raczej rekonstrukcjami niż rekapitulacjami naszych doświadczeń, a na te rekonstrukcje wpływ ma nie tylko to, kim kiedyś byliśmy, ale również to, kim się staliśmy, nie tylko przeszłość, ale również teraźniejszość, w której wspomnienia są przywoływane ${ }^{31}$.

Chociaż sformułowanie to niektórym wydawać może się oczywiste, to warto przeczytać je w kontekście obrazu fotograficznego, któremu kulturowo przypisywana jest przecież niezmienność.

Nawet jeśli opowiadamy to samo zdarzenie raz za razem, to każda z tych narracji będzie inna. Dobrze tę plastyczność narracji ilustruje, wielokrotnie przywoływany przez badaczy wizualnych, film dokumentalny zrealizowany w roku 1972 przez Liane Brandon ${ }^{32}$. Betty tells her story jest zapisem wywiadu z tytułową Betty, opowiadającą o ważnym dla niej zdarzeniu. Betty wspomina wydarzenie sprzed lat, gdy została zaproszona na uroczyste przyęcie. Słyszymy więc, jak Betty, przejęta okolicznościami, kupiła suknię za drogą jak na jej możliwości finansowe i - ostatecznie - jak suknię tę przypadkowo zgubiła. Gdy Betty kończy opowieść, reżyserka prosi ją, by powtórzyła narrację. Narratorka opowiada powtórnie, lecz tym razem odmiennie rozkłada akcenty. Otrzymujemy historię o czymś innym: o lękach i nadziejach, braku poczucia własnej wartości, zawiedzionych marzeniach, o chwilowym poczuciu bycia piękną, o utracie, której nie da się już odwrócić. W wywiadzie pierwszym Bet-

30 Draaisma, Ksiega zapominania, s. 23.

${ }^{31}$ Ibidem, s. 22-23.

32 Betty Tells Her Story, reż. Liane Brandon, 20 min., 1972. 
ty jest spokojna, opowiada zdarzenia jak anegdotę, w drugim - opowieść jest emocjonalna i poruszająca.

Ta narracja - współczesnego Kopciuszka, ale bez szczęśliwego zakończenia - pokazuje, że wspomnienia są konstruowane w akcie wypowiedzenia. Betty powraca do przeszłości, lecz jednocześnie rekapituluje całe swoje życie od zdarzenia do współczesności. Betty opowiadała, rekonstruując fragmenty zapisane w pamięci, a ponieważ czyniła to już wcześniej - jeszcze przed realizacją filmu wiele razy - mogła swoją wypowiedź swobodnie konstruować, nie po to, by tworzyć narrację fikcyjną, lecz by dopasować ją do sytuacji opowiadania, realizacji filmu. Czy jeśli oparłaby swoją opowieść na zdjęciach, rekonstrukcja byłaby bardziej powtarzalna? Niekoniecznie. Fotografia daje nam obraz, lecz nie gwarantuje powtarzalności opowieści. Badacz mediów cyfrowych José van Dijck dla opisania interakcji fotografii (ale także filmu i wideo) z pamięcią wprowadza kategorię „mediowanych obiektów pamięci” i zauważa, że "nigdy nie reprezentują one uchwyconego momentu; służą utrwaleniu chwilowych wyobrażeń oraz relacji, zachodzących pomiędzy przeszłością i teraźniejszością"33. Obrazy pozwalają komunikować się nam z przeszłością, lecz same pamięcią nie są. Van Dijck podkreśla ich kulturowy charakter i zauważa, że pamięć „nadpisuje” coraz to nowe treści wspomnień. Holenderska autorka ilustruje swoją tezę przykładami dwu filmów: Memento Christophera Nolana i Zakochany bez pamięci (Eternal Sunshine of the Spotless Mind) Michela Gondry'ego i Charliego Kaufmana (znaczące, że są to najczęściej chyba przywoływane obrazy filmowe we współczesnej literaturze poświęconej pamięci autobiograficznej). W obu fabuła krąży wokół pytania o fizyczną ingerencję w mózg, zakłócającą działanie pamięci. W pierwszym filmie główny bohater - Leonard, cierpiący na zanik pamięci krótkotrwałej - „wspiera” swoją wiedzę o wydarzeniach z poprzedniego dnia fotografiami polaroidowymi, w drugim protagonista, Joel, poddaje się zabiegowi wymazania wspomnień o niechcianej miłości. Warunkiem powodzenia operacji jest także usunięcie wszelkich przedmiotów i obrazów wiążących się z ukochaną Clementine. „Mediowane obiekty pamięci” (mediated memory objects) nie są jednak w opinii van Dijck tylko „protezami umysłu”, lecz są pochodną zarówno pracy jednostkowej pamięci, jak i obiektów kultury materialnej i przypisywanych im znaczeń ${ }^{34}$.

Warto w tym miejscu przyjrzeć się rozumieniu terminu „mediowany obiekt pamięci" i zastanowić się, na ile jego znaczenie zmienia wraz z pojawieniem się kultury cyfrowej. Van Dijck stwierdza, że „cyfrowa fotografia zna-

\footnotetext{
${ }^{33}$ J. van Dijck, Mediated Memories in the Digital Age, Stanford, California, 2007, s. 17.

34 Ibidem, s. 28.
} 
komicie odpowiada morfującej w czasie naturze ludzkiej pamięci"35. Ponieważ zakodowane dane cyfrowej reprezentacji są o wiele bardziej podatne na manipulację, a także swobodnie przemieszczają się między nośnikami: smartfonami, blogami, portalami społecznościowymi, a także tradycyjnymi wydrukami, obiecują nie tylko przetrwanie zapisanych obrazów przeszłości, lecz także ich dopasowanie do teraźniejszości ${ }^{36}$. Wydaje się zatem, że można bez końca je przetwarzać i odtwarzać. Badaczka mediów uznaje jednak takie przekonanie za jeden z mitów kultury cyfrowej. „Mediowane obiekty pamięci” należą do nowego typu cyfrowej materialności, równie jednak jak dawne obrazy podatnej na zniszczenie. Nie znamy jeszcze ostatecznej trwałości nośników takich jak CD-ROM-y (notabene wypieranych przez pendrive'y) ani nie potrafimy przewidzieć, która $z$ technologii przechowywania zapisu cyfrowego (pamięci zewnętrzne czy technologie chmury) będzie stosowana nawet nie za sto, ale za dwadzieścia lat. Można więc powiedzieć, że wystarczy zmiana technologii lub awaria serwera, by część tych „remediowanych” kotwic pamięci utracić.

Istotna różnica między fotografią fotochemiczną i cyfrową nie polega na ich podatności na zniszczenie, lecz na zasięgu kultury cyfrowej. Jak pisze autorka: „osobista pamięć kulturowa uwalnia się z "pudełka na buty» i staje się częścią globalnej kultury cyfrowej - bezprzewodowego świata, który okazuje się nasycony niewidzialnymi nitkami łączącymi umysł, materię i wyobraźnię" ${ }^{37}$. Specyficznie w tej kulturze zmienia się miejsce fotografii, która w równym stopniu jak inne technologie medialne przestaje być przypisana jednemu nośnikowi i - zgodnie $z$ ideą konwergencji - zmienia przestrzeń, której jest przypisana. Skanowana, „przyszpilana” do cyfrowych tablic, uruchamiana w realizacjach filmowych ${ }^{38}$, nieustannie wędruje, Proteuszowo zmienia swoją postać. Przestaje być „prywatna” i zostaje poddana oglądowi innych. I znowu, nowość tego doświadczenia jest ilościowa, nie jakościowa - kiedyś także albumy z fotografiami pokazywaliśmy innym, teraz jednak dostęp do nich ma nieporównanie więcej osób, nie zawsze powiązanych z nami ścisłymi więzami rodzinnymi czy przyjacielskimi.

Dlaczego jednak tak wiele wynalazków zostało stworzonych w konsekwencji obsesyinej potrzeby pamiętania? Draaisma sprawę ujmuje ewolucjonistycznie: pamięć służy ochronie gatunku przed trudnościami. Dlatego pew-

35 Ibidem, s. 47.

${ }^{36}$ Czego teoretyczną egzemplifikacją są koncepcje mediów konwergentnych. Zob. H. Jenkins, Kultura konwergencji, tłum. M. Bernatowicz, M. Filiciak, Warszawa 2007.

37 Van Dijck, Mediated Memories..., s. 52.

38 I nie chodzi tu jedynie o filmy o fotografiach, jak na przykład Szukając Vivian Meier (2014) Johna Maloofa i Charliego Siskela, lecz o realizacje filmowe wykorzystujące fotografię jako materiał przetworzenia. 
ne rzeczy ( $z$ reguły te, których rolą jest nas przestrzegać) pamiętamy, a inne zapominamy ${ }^{39}$. Także van Dijck wiąże pragnienie pamiętania $z$ instynktem przetrwania, jednak w większym stopniu uwzględnia kulturową rolę procesu. Ludzie „[...] przywiązywali wagę do tworzenia i zachowywania śladów ich samych - myśli, wyglądów, głosów, uczuć i idei. Mogli pragnąć, by te obrazy były wiarygodne lub idealizujące, realistyczne lub pochlebne, lecz przede wszystkim, by były pamiętane" ${ }^{\prime 20}$. Czy jednak ten fotograficzny ślad, rodzaj zewnętrznej hypomneme, nie przysłania nam mneme, żywej pamięci, zmieniającej się wraz z jej nosicielem? By odpowiedzieć na to i inne jeszcze pytania, które stawia przed nami problematyka pamięci autobiograficznej, posłużę się przykładami działań artystycznych.

\section{PAMIĘĆ AUTOBIOGRAFICZNA W PRAKTYCE FOTOGRAFÓW}

\section{MORFOWANIE - ZOBACZYĆ SIEBIE JAKO INNEGO}

Wspomniałam wcześniej o uwadze van Dijck o „morfującej w czasie, naturze ludzkiej pamięci”. Jej artystyczną ilustracją mogłyby być prace Nancy Burson, którą interesuje zarówno to, jak ludzie postrzegają siebie w czasie, jak i to, jak postrzegaliby siebie, gdyby mogli zmieniać własną przynależność etniczną. W roku 2000 Burson zaczęła realizować projekt zatytułowany The Human Race Machine. Artystka wykorzystywała możliwości cyfrowych technik morfowania, by pokazać, jak dana osoba wyglądałaby po dokonaniu niewielkich ingerencji w kształt twarzy, wykrój oczu, kolor skóry. Widz/uczestnik pracy siada przed ekranem i za pomocą interaktywnego oprogramowania, gdy kamera zarejestruje jej/jego twarz, może jednocześnie zmodyfikować jej kształt i kolor, nadając rysy odmienne od własnej grupy etnicznejej ${ }^{41}$ Burson następująco uzasadnia działanie urządzenia: The Human Race Machine „, $[. .$. daje możliwość przeżycia unikatowego, osobistego doświadczenia bycia kimś innym niż jesteśmy. Jesteśmy jedną rasą, ludzką; jednym narodem nazywanym ludzkością"42. Burson w realizacji pokazuje, że warunkiem koniecznym przyjęcia określonej tożsamości jest zobaczenie siebie jako kogoś innego. W tym akcie zderzony zostaje zapamiętany przez widza obraz siebie $z$ wersją

39 Draaisma, Ksiega zapominania, s. 48.

40 Van Dijck, Mediated Memories..., s. 52.

${ }^{41}$ W roku 2016 Burson zrealizowała animowaną pracę What if He Were: Black-Asian-Hispanic-Middle Eastern-Indian, pokazującą różne wersje twarzy Donalda Trumpa.

${ }^{42}$ The Human Race Machine [online], 2016, <http://www.humanracemachine.com/> [dostęp: 28 stycznia 2017]. 
podsuwaną przez program. Wyobraź sobie, kim jesteś - zdaje się podpowiadać artystka. Praca Burson jest kolejną z cyklu działań z interaktywnymi urządzeniami, tworzonymi od lat 80 . Wcześniej powstały Composite Machines, pozwalające odbiorcom zestawiać własny portret z wizerunkiem sławnej osoby, czy Age Machines, która pozwalała „postarzyć” własną twarz i zobaczyć siebie po latach. Realizacja ma niewątpliwie emancypacyiny, równościowy i jednocześnie edukacyjny wydźwięk, jednak mnie w kontekście prezentowanych tu rozważań bardziej od kulturowo i społecznie krytycznych odniesień interesuje to, czy w zmienionych twarzach użytkownicy oprogramowania są w stanie zobaczyć „siebie”? Nakładają się tu dwie warstwy rozważań. Po pierwsze: czy wiemy, jak wygląda nasza twarz? Po drugie: czy potrafimy rozpoznać ją pośród innych?

Nie wchodząc tutaj w fascynującą lekturę fotografii jako farmakonu ${ }^{43}$, w kolejnej części tekstu odpowiem na to pytanie, korzystając z podpowiedzi Draaismy tłumaczącego to, jak pamiętamy twarze. Zdjęcia portretowe, przekonuje autor Księgi zapominania, wspierając się argumentami Rudy'ego Kousbrocka, zastępują wspomnienia - tłumią je i wchodzą w ich miejsce. „Kto fotografuje, nie ma potem wspomnień i zdjęcia, ale wspomnienia od samego początku prześwitują przez zdjęcie, a po pewnym czasie zdjęcie staje się częścią wspomnień" ${ }^{44}$. Psycholog pyta, dlaczego tak się dzieje i znajduje odpowiedź w mechanizmie odświeżania pamięci twarzy. Chociaż obejmująca zapamiętywanie twarzy pamięć wzrokowa ma ogromną pojemność, to nie jest niewyczerpywalna. Nie chodzi więc o zdolność pamiętania, lecz rozpoznawania - aktualizowania informacji zapisanej w pamięci ${ }^{45}$.

Czy jednak możemy pamiętać siebie jako innego? Umysł zastępuje wizerunki wcześniejsze kolejnymi. Teorie psychologów każą nam krytycznie spojrzeć na poglądy teoretyków obrazu. Fotografia nie dlatego mocniej zapada nam w pamięć, że jest nieruchoma, lecz dlatego że pamięć się odnawia, zastępując wcześniejszy obraz kolejnym ${ }^{46}$.

${ }_{43}$ Zob. M. Michałowska, Foto-teksty. Zwiqzzki fotografii z narracja, Poznań 2012, s. 204-210.

44 Draaisma, Ksiega zapominania, s. 277.

45 Ibidem, s. 178.

${ }^{46}$ Interesująca jest w tym kontekście ponowna lektura ostatniej części W poszukiwaniu straconego czasu Marcela Prousta. Jak pamiętamy, narrator uczestniczący w przyjęciu jest uderzony tym, jak bardzo postarzały się twarze osób, które znał. Moglibyśmy to odczucie tłumaczyć tym, że - ponieważ długo ich nie widział - nie zachodził mechanizm „odświeżania" pamięci, przez co pomiędzy obrazem zapamiętanym i widzianym nastąpiła wyraźna luka. 
Czy rzeczywiście musimy przyjąć tłumaczenie psychologa? Fenomenolog podałby inną interpretację. Paul Ricoeur, pisząc w Drogach rozpoznania, że „akt rozpoznania jest aktem par excellence mnemonicznym" ${ }^{\prime 4}$, jest przekonany, że w pamięci musi istnieć jakiś rodzaj wspomnienia „czystego”, pierwotnego. Skoro bowiem można coś rozpoznać, to znaczy, że odnajdujemy to, co wcześniej musiało istnieć. Filozof uznaje, że podstawą tego rozpoznania są trzy kategorie śladów: ślady w korze mózgowej, psychiczne ślady wrażeń i ślady dokumentalne przechowywane w publicznych i prywatnych archiwach.

Rozpoznawanie własnej twarzy jest jeszcze bardziej skomplikowane, bo do kwestii rozpoznawania wizerunków dochodzi pytanie o wyobrażenie siebie. „Ja" zostaje wyobrażone przez sam podmiot niejako „od wewnątrz", co włącza w mechanizm rozpoznawania całą gamę oczekiwań, które tenże podmiot wobec siebie stawia. Czy zatem, prowadząc interakcję z maszynami Burson, będziemy w stanie rozpoznać w zmienionej twarzy siebie? Lub poczuć, jak by to było wyglądać inaczej? I czy wystarczy „wyglądać inaczej”, by być kimś innym? Pewność podmiotu co do własnej tożsamości tylko w niewielkim stopniu związana jest $z$ warunkiem wizualnego podobieństwa. $W$ istocie jest to proces, w którym stajemy się, zmieniamy, przyjmujemy odpowiedzialność za kolejne czyny i który nie ustaje aż do końca ludzkiej egzystencji. Dlatego też rozpoznanie siebie, jak pisze Ricoeur, jest czymś „nieziszczalnym”48.

\section{SYNTETYZOWANIE - ROZPOZNAWANIE INNYCH}

Przywoływani w tekście teoretycy: Draaisma, van Dijck czy Ricoeur, zgadzają się, że pamięć ma charakter narracyiny. Zatem, by dostrzec, kim się jest i osadzić tożsamość własną wobec innych, musimy przeszłość sobie opowiedzieć, chociażby analizując własne wizerunki. Dokonać tego można poprzez proces porównywania swojej twarzy $z$ twarzami innych. Ponownie ilustracji dla tej argumentacji dostarczą prace Burson.

The Human Race Machine nie była pierwszym projektem Burson, eksperymentującym $z$ twarzami. Wcześniej artystka tworzyła przedstawienia, będące syntezą portretów ikonicznych postaci współczesnej kultury. First and Second Beauty Composites (1982) były fotomontażami, do których stworzenia użyto wizerunków: Bette Davis, Audrey Hepburn, Grace Kelly, Sophii Loren i Marilyn Monroe (pierwszy) oraz Jane Fondy, Jacqueline Bisset, Diane Keaton, Brooke Shields i Meryl Streep (drugi). Amerykańska artystka uzyskała w ten sposób modele charakterystycznych dla epoki wyobrażeń idealnej

\footnotetext{
47 Ricoeur, Drogi rozpoznania, s. 117.

48 Ibidem, s. 57.
} 
kobiecej twarzy. W pracach $z$ lat 80 . Burson posługiwała się jeszcze techniką fotochemiczną, której źródeł można doszukiwać się chociażby w fotografii kompozytowej Francisa Galtona. Jednak jej typologia, inaczej niż twórcy eugeniki, nie aspirowała do stworzenia teorii nowego społeczeństwa, w którym to rysy twarzy decydowałyby o wykluczeniu lub uznaniu za reprezentanta rasowej doskonałości. W istocie Burson krytycznie i ironicznie komentowała tego rodzaju praktyki. Znakomicie to ilustruje praca Warhead I (1982). Burson tworzy wizerunek wyobrażonego dyktatora, oceniając jego znaczenie potencjałem nuklearnym kraju. W rezultacie powstała synteza oparta w 55 proc. na portrecie Reagana, w 45 proc. na wizerunku Breżniewa, w mniej niż 1 proc. na zdjęciach Margaret Thatcher, François Mitteranda i Deng Xiaopinga. Używana przez Burson metoda fotografii kompozytowej ${ }^{49}$ przywołuje na myśl prace realizowane przez innych artystów. Jednym $z$ najciekawszym twórców „fotosyntez” jest, w mojej opinii, Krzysztof Pruszkowski. Spośród wielu prac, w których autor nakłada na siebie wizerunki ludzi lub przedmiotów ${ }^{50}$, uwagę przykuwa Hołd dla pięciu ostatnich lat życia "modelowego modela" Jacoba Israela Avedona, 1969-1973 (1986). Z szaro-czarnej plątaniny linii i płaszczyzn wyłaniają się ciemne oczodoły i dziwacznie w uśmiechu wyszczerzone zęby. Zdaje się, jakby te zapisy wielu twarzy tego samego mężczyzny zapowiadały to, co nieuniknione - nadchodzącą śmierć. Praca Pruszkowskiego dobrze podkreśla narracyiność procesu pamięciowego. Kolejne nałożone na siebie warstwy stanowią odpowiednik narracji o ludzkim życiu, które trzeba sobie opowiedzieć, by zrozumieć, kim był jego (życia) bohater.

Fotografia zawsze była traktowana jako ucieczka przed śmiercią, nieruchomością - stąd usilne starania fotografów mortualnych, by pokazać zmarłych jak żywych ${ }^{51}$. Wydaje się zatem, że marzeniem i fotografów, i samych portretowanych było uchwycenie tego, co ruchome i zmienne. Czy fotografia jest w stanie uchwycić tę zmienność, która dla obrazów "ja” powstających w pamięci jest typowa? Roland Barthes pisze następująco o tym usilnym pragnieniu znalezienia równowagi pomiędzy tym, co widzialne, i tym, co wyobrażone:

49 Tak Leszek Brogowski proponuje tłumaczyć termin composite photography, zob. L. Brogowski, O ideale obróconym w dowcip. Fotografia kompozytowa Francisa Galtona i jej oddźwięki, „Dyskurs” 2013, 5, s. 70-102.

50 Jak na przykład: 60 pasażerów pierwszej klasy metra. Linia: Vincennes-Neuilly, Paryż, 9 czerwca 1985 roku. Między godz. 9 i 11 (1985); lub 10 Afrodyt z Muzeum Grecko-Rzymskiego w Aleksandrii (1989/1993).

51 Zob. Draaisma, Księga zapominania, s. 269-275; T. Ferenc, Odrzucony język fotografii mortualnej, w: Przestrzenie fotografii. Antologia tekstów, red. T. Ferenc, Łódź 2005, s. $79-108$. 
Ponieważ jednak chciałbym, aby została uchwycona delikatna tkanka moralna, a nie jakaś chwilowa mimika, i ponieważ Fotografia nie jest zbyt subtelna (poza dziełami wielkich portrecistów), nie wiem, jak działać od wewnątrz na swoją skórę [...] tak więc chciałbym, aby mój obraz, ruchomy, wstrząsany pomiędzy tysiącem zmieniających się zdjęć, zależnie od okoliczności i wieku, zgadzał się zawsze z moim „ja” (głębokim, oczywiście) ${ }^{52}$.

„Fotosyntezy” (czyli wświetlenia wielu negatywów w jeden obraz) Pruszkowskiego wydają się bliższe ideałowi, do którego tęskni Barthes, od tradycyjnych portretów fotograficznych. Na portrecie Jacoba Israela A... z twarzy modela bije spokojna pewność własnej osoby, świadomość tożsamości. Zdjęcia zmieniają się przed naszymi oczyma, chociaż cały czas patrzymy przecież na ten sam kadr. Fotograf, „fotosyntetyzując” ostatnie pięć lat życia modela, osiągnął to, czego pragnie filozof. Oto przez przezroczystą „skórę" wielu warstw nałożeń prześwituje „ja”.

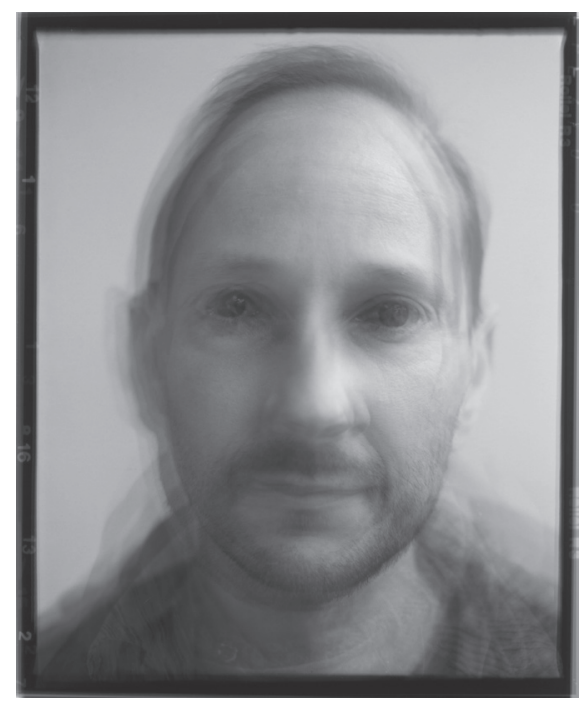

1. Marek Lalko, 10 dni, z cyklu N, 2015, fotografia cyfrowa, dzięki uprzejmości autora

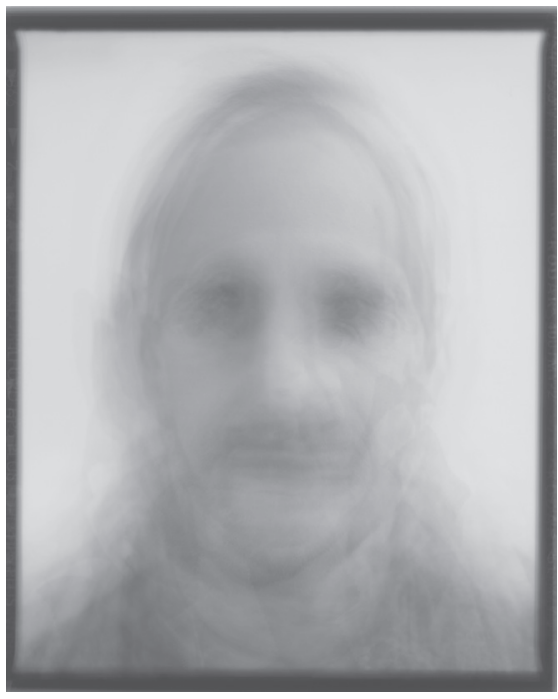

2. Marek Lalko, 100 dni, z cyklu N, 2015, fotografia cyfrowa, dzięki uprzejmości autora

Podobną strategię - zamknięcia w kadrze wycinka życia modela - stosuje Marek Lalko. Artysta fotografuje swojego przyjaciela na jego prośbę. Fotografie robione są raz, dwa razy na tydzień. Dokumentują wygląd modela, ale także zaświadczają o istnieniu tego konkretnego człowieka w danym momencie.

52 R. Barthes, Światło obrazu, tłum. J. Trznadel, Warszawa 1996, s. 21. 
Zdjęcia rejestrują drobne zmiany w wyglądzie i stroju, ale także to, co pokazać o wiele trudniej - upływ czasu. Następnie Lalko nakłada te "kalki czasu” na siebie. Inaczej niż Burson we wczesnych portretach i Pruszkowski, fotograf dokonuje swoich fotosyntez cyfrowo. W myśl koncepcji Ricoeura, moglibyśmy zadać pytanie, jak to się dzieje, że w modelu, pozującym do zdjęcia Markowi Lalko, rozpoznajemy konkretną postać?

Sednem koncepcji tożsamości narracyjnej Paula Ricoeura jest współzależność pomiędzy dwoma składnikami tożsamości - trwałej idem i zmiennej ipse. Oba pozostają w zmiennej relacji, tworząc dialektyczną całość: „takożsamość" (mêmeté) i "tożsamość" (ipséite). Fenomenolog używa porównań rozwijających odniesienie do fotografii: bo z jednej strony czynnik idem zostaje przyrównany do „tożsamości biologicznej, sygnowanej kodem genetycznym, oznaczanej za pomocą odcisków palców" ${ }^{\prime 53}$, z drugiej zaś ipse rozwija się w „obszarze fikcji polegającej na wytwarzaniu mnóstwa zachodzących w wyobraźni zmian" 54. Przekładając to na zdjęcie, powiedzielibyśmy, że fotograficznym idem jest to, co zostało nieodwołalnie zarejestrowane na nośniku, ipse zaś jest nieustającym procesem przypominania sobie tego, co sfotografowane - ruchem pamięci autobiograficznej. Ów ruch, jak pisałam już wcześniej, polega na zastępowaniu obrazów wcześniejszych kolejnymi. Przypominając sobie siebie wcześniej, tworzymy ślad wspomnienia, gdy ponownie będziemy sobie obraz siebie przypominać, ów ślad „zaktualizujemy”. Jest to zatem nieustający ruch zachodzący pomiędzy kolejnymi obrazami siebie.

Fotograficzne ipse (można by je opisać jako „stawanie się") wychodzi poza ramy działania naszego umysłu i obejmuje także wszelkie możliwe zmiany, które zawarte są w repertuarze technologii: fotochemiczne gradacje wywołań i doświetleń negatywu lub zapisane w algorytmie potencjalne przekształcenia cyfrowego kodu.

Ricoeur pisze, że idem to tożsamość rozpoznawalna, przypisana jednostce, z kolei ipse to wszystko, co sprawia, że tożsamość jest „zamazana i nieczytelna" ${ }^{\prime 55}$. Fotosyntezy Pruszkowskiego (jak też obrazy Marka Lalko) są rozmyte, nieczytelne właśnie, jednak przebija przez tę nieostrość zespół podobieństw powtarzalnych cech, w efekcie wyłania się twarz człowieka, którego moglibyśmy rozpoznać z innych wizerunków. Filozof mówi, że rozmycie ipse prowokuje postawienie pytania: „Kim jestem?”. Tej odpowiedzi udzielić można tylko opowiadając. W istocie, by dowiedzieć się, kim jest mężczyzna na zdjęciu, potrzebujemy nie tylko jego obrazu, potrzebujemy jeszcze opowieści: autobiografii lub biografii, czyli świadectwa fotografa, który nam o nim opowie.

\footnotetext{
53 Ricoeur, Drogi rozpoznania, s. 90.

${ }^{54}$ Ibidem, s. 91.

${ }^{55}$ Ibidem.
} 


\section{TIME LAPSE: ŻYCIE W 3 MINUTY}

Skoro pamięć jest procesem dziejącym się w czasie, to wydaje się, że również opowieść o niej powinna być realizowana za pomocą mediów raczej ruchomych niż nieruchomych. Dlatego zapewne autorzy prac biograficznych tak chętnie sięgają do środków filmowych (lub parafilmowych, jak montaż fotograficzny). Najczęściej jednak realizacje autobiograficzne można zaliczyć do obszaru still/ movies, czyli technik płynnie wędrujących między obrazem nieruchomym i ruchomym. Dobrym przykładem mogą być tu realizacje przeznaczone do prezentacji w sieci (na portalach społecznościowych lub na kanałach YouTube lub Vimeo). Zauważmy jednocześnie, że te internetowe montaże zdjęć albumowych lub portretowych mogłyby być realizacją marzenia Barthes'a o portrecie zmieniającym się (dziejącym się) w czasie. W technice animacji poklatkowej (time lapse) zdjęcia pokazujące bohaterów w różnym wieku wyświetlane są przed oczyma widzów na tyle szybko, by w ich umysłach „sklejały się”, dając wrażenie morfizacji. Przykładem może być film Fransa Hofmeestera Portrait of Lotte, 0 to 16 years in 4" minutes. Twórca raz w tygodniu fotografował i filmował swoją córkę. Następnie materiał zmontował w czteroipółminutową całość. Widzimy Lotte jako niemowlę, dziecko, nastolatkę. W filmie wyraźnie zaznacza się rodzicielskie zapatrzenie w dziecko, ale też pragnienie uczynienia ważnym codziennego doświadczenia. Ten film jest jednak przykładem pamięci nie tyle autobiograficznej, ile biograficznej. Stanowi bowiem zapis tego, jak dziecko jest postrzegane przez ojca. Czy po latach Lotte rozpozna w filmie siebie i uczyni ten zapis fragmentem własnej autobiografii?

Internetowe filmy można potraktować jako wizualizację procesu „odświeżania obrazów". W naszej pamięci obraz wcześniejszy zastępowany jest tym, który powstaje $\mathrm{w}$ procesie przypominania sobie. $\mathrm{W}$ technice time lapse wcześniejszy obraz także zanika podczas oglądania filmu, ale powraca, jeśli obejrzymy film ponownie. Time lapse stanowić mógłby następny etap wcześniejszych portretów multiplikowanych (jak wielkie projekty Romana Opałki czy Nicolasa Nixona). Najczęściej jednak odnajdujemy tego rodzaju strategię w codziennych praktykach sieciowych. Technikę biograficznej i autobiograficznej animacji poklatkowej można potraktować jako modną ciekawostkę lub rytuał podobny do strategii budowania albumów rodzinnych. Kiedy wpisałam pracę Hofmeestera w wyszukiwarkę, algorytm podpowiedział mi dziesiątki innych przedstawień - fotografie dzieci regularnie wykonywane przez rodziców czy selfie - montowane w filmy obejmujące kilka miesięcy lub lat ${ }^{56}$. Popularność techniki wskazuje, że dla odbiorców możliwość zobaczenia sie-

56 Pomijam cały nurt autobiograficznych animacji poklatkowych, pomagających autorom poradzić sobie $z$ traumą choroby, żałobą czy śmiercią. 
bie, bliskich - czy nawet zupełnie obcych osób - w przyspieszonym tempie jest atrakcyjna. Niewątpliwie ten rodzaj pamięci mediowanej konstruowany jest w taki sam sposób jak album rodzinny - dostosowany do oczekiwań tego, kto będzie album czy film oglądał. Marianne Hirsch uważa, że rozpoznanie zdjęć naszych bliskich w fotografiach historii rodzinnej - paradoksalnie - nie jest $w$ istocie rozpoznaniem tego, co znamy $z$ autopsji:

Zasadniczo jest to gest interpretacyjny i narracyiny, fabrykacja dostępnych fragmentów, które potwierdzają fragmentaryczną naturę aktu autobiograficznego i niejednoznacznej relacji do przedmiotu odniesienia. Fotografie są fragmentami historii, nigdy nie są historiami samymi w sobie ${ }^{57}$.

Czy jednak twórcy filmów poklatkowych są w stanie trafnie przewidzieć sposób ich recepcji? Michael Gloger zmontował film całkowicie złożony z selfie - Time lapse of me growing up. 4 years in 2 minutes $^{58}$. Warstwie wizualnej towarzyszy warstwa dźwiękowa - utwór brytyjskiej grupy Massive Attack, Teardrop. Długość piosenki wyznacza długość filmu oraz nadaje całości specyficzny rytm. Praca Glogera w prosty sposób, zgodnie z linią czasu (timeline) pokazuje cztery lata życia młodego człowieka. Autor/bohater filmu fotografował się (niemal zawsze) w prywatnej przestrzeni domu. Dzięki temu 1640 zdjęć użytych do realizacji filmu uzmysławia nam nie tylko to, jak Michael zmienia się z nastolatka w młodego dorosłego - jak dorasta i poważnieje, ale także jak zmienia się miejsce, w którym żyje, oraz jego zainteresowania. $\mathrm{W}$ pewnym momencie w tle pojawiają się przyjaciele, dziewczyna. Time lapse wydaje się praktyką, która świetnie spełnia założenia narracyjności biografii. Otrzymujemy opowieść o wycinku życia i możemy w ciągu kilku minut dostrzec zmiany zachodzące przez lata w podmiocie opowieści.

Miejsce prezentacji internetowych filmów poklatkowych wpływa na ich recepcję. Podobnie jak inne filmy umieszczane na kanale YouTube, widzowie mogą komentować realizacje time lapse. O ile komentarze pod filmem Hofmeestera były w większości przychylne, jakby widzowie byli rozbrojeni emocjami dumnego rodzica, o tyle zestaw selfie Glogera zostaje odebrany krytycznie. Oglądających drażniło narcystyczne nastawienie autora. Refleksji została poddana także sama technika poklatkowa. Komentator FroQQer pisze: „Wkrótce będziemy mieli time lapse’y czyjegoś życia od początku do końca. Czy nie byłoby wspaniale to zobaczyć?!" ${ }^{29}$. Czy jednak rzeczywiście kolejna

\footnotetext{
57 M. Hirsch, Family Frames. Photography narrative and postmemory, Cambridge, Massachusetts, London 2002, s. 83.

$58<$ https://www.youtube.com/watch?v=FdeKk5_oXXg>

59 Komentarz na forum internetowym, autor: FroQQer, < https://www.youtube.com/ watch?v=gt3qvDCveOE $>$ [dostęp: 31 stycznia 2017].
} 
multiplikacja obcych twarzy może nas zainteresować? To ten sam problem, który znajdujemy w albumie rodzinnym - oglądanie cudzych zdjęć, z reguły, jest potwornie nudne.

\section{SELFIE - WSPÓ£DZIELENIE OBRAZU}

Prace, które opisywałam wcześniej - Burson, Pruszkowskiego, Marka Lalko, w większości nie były pracami autoportretowymi - pokazywały innych, można nazwać je zatem biograficznymi. W ostatniej części tekstu czas podążyć dalej i przyjrzeć się jednemu z najpopularniejszych współczesnych wcieleń pamięci autobiograficznej. Punktem wyjścia rozważań uczynimy wprowadzoną wcześniej jedną z technik globalnej kultury cyfrowej - selfie. Ten gatunek wizualny - przez jednych odsądzany od czci i wiary, przez innych uznawany za jeden z najważniejszych wyznaczników współczesnej tożsamości - jest w teorii obrazu interpretowany na dwa sposoby. W pierwszym odczytaniu uznawany jest za kontynuację i przeobrażenie tradycji portretowej, $\mathrm{w}$ drugim ważniejszy od wizualnej formy selfie jest komunikacyjny charakter obrazu, to, że jest narzędziem nieustannego bycia z innymi.

Przyjrzyjmy się najpierw pierwszej drodze: jak pisze Nicolas Mirzeoff, selfie są przejawem procesów demokratyzacji kultury. Sztuka portretowa, zauważa badacz kultury wizualnej, zawsze była elitarna, a wraz z pojawieniem się fotografii coraz bardziej powszechnieje (nie bez znaczenia jest ekonomiczna dostępność technik obrazowania), by wreszcie stać się dostępna każdemu. Autor Jak zobaczyć świat? pisze: „praktyki w przeszłości elitarne stają się częścią globalnej kultury wizualnej”60.

Czy jednak rzeczywiście da się wywieść selfie z praktyki autoportretowej? Najwyraźniej tak uważają kuratorzy londyńskiej Saatchi Gallery, zapowiadając na marzec 2017 roku otwarcie wystawy zatytułowanej „From Selfie to Self-Expression" ${ }^{\prime 61}$. Wśród prac na wystawie znajdą się autoportrety Rembrandta, Velázqueza i van Gogha, prace Juno Calypso, Cindy Sherman i Kutluğa Atamana, a także selfie pokazujące aktora Benedicta Cumberbatcha skaczącego za grupą celebrytów podczas rozdania Oscarów czy fotografię Roberta Schmidta pokazującą premier Finlandii Helle Thorning-Schmidt, fotografującą się z Barackiem Obamą i Davidem Cameronem na pogrzebie Nelsona Mandeli. Wystawie towarzyszy konkurs oznaczony hasztagiem \#SaatchieSelfie. Najlepsze nadesłane zdjęcia zostaną pokazane na wystawie.

\footnotetext{
${ }^{60}$ Mirzeoff, Jak zobaczyć świat, s. 44.

${ }^{61}$ Informacje o wystawie można znaleźć m.in. na stronach Saatchi Gallery, zob. <http:// www.saatchigallery.com/selfie/> [dostęp: 31 stycznia 2017].
} 
Kurator wystawy Nigel Hurst twierdzi, że selfie stanowi dzisiaj jedno z najważniejszych narzędzi autoekspresji ${ }^{62}$. Potwierdza tym samym obserwację brytyjskiego badacza wizualnego, zakładającego, że ten typ obrazu „jest połączeniem wyobrażenia o sobie, autoportretu artysty jako bohatera i obrazu technicznego właściwego sztuce nowoczesnej - połączeniem pełniącym funkcję cyfrowego performansu" ${ }^{\prime 3}$. Nietrudno dostrzec, że zgodnie $z$ tą interpretacją autoportret jest rozumiany jako nieustanne odgrywanie „siebie”, próbowanie możliwości stawania się innym. Ujmuje zatem znakomicie Ricoeurowską dialektykę mêmeté i ipséite - tożsamości możliwej do zaistnienia w przyszłości - jak w autoportretowych performansach Atamana lub (by do grona wystawianych w Saatchi artystów dołączyć nazwisko polskie) w setkach fotograficznych autoportretów Tomasza Machcińskiego, opowiadającego siebie jako postaci realne: Gretę Garbo, Józefa Piłsudskiego, czy mityczne: Satyrów i Faunów.

Gdybym miała szukać różnic między tym, co wydarza się w autoportrecie, a tym, co w selfie, to znalazłabym je w celu, do którego dążą twórcy jednych i drugich. Autoportrety są refleksyjnie skierowane ku sobie, selfie lo czym także pisze Mirzeoff) - ku innym, z założeniem, że będzie ono komentowane, „lajkowane”, przesyłane z prywatnego ${ }^{64}$ smartfona do Instagrama, „podpinane" do tablic Pinterestu.

Ciekawie relacje prywatne-publiczne komentuje praca Selfportrait with a Webcam, zrealizowana przez multimedialistę Josefa Klammera podczas festiwalu Ars Electronica w roku 2007. W pracy widzimy artystę siedzącego $z$ laptopem na kolanach i patrzącego w przestrzeń. Klammer fotografował siebie za pomocą kamer miejskiego monitoringu, obserwując własny wizerunek na ekranie laptopa, jednocześnie dostarczał informacji o lokalizacji danego autoportretu. Marcus Maida wyjaśnia: „To przewrotna odpowiedź Klammera na wielką tradycję zachodniego autoportretu, odpowiedź pozbawiona typowej dla niego pompatyczności i melodramatu, przenosi ona gatunek w sferę rozważań nad pęknięciem pomiędzy sferą publiczną i prywatną" ${ }^{\prime 65}$. Autoportret w wersji selfie nie jest już rozważaniem o podmiotowości autora, ale funkcjonalnym narzędziem komunikacji.

62 Saatchi gallery to explore selfies as art form, „The Guardian” [online] oraz Guardiana, zob. [online] < https://www.theguardian.com/artanddesign/2017/jan/23/saatchi-gallery-to-explore-selfies-as-art-form-self-expression> [dostęp: 31 stycznia 2017].

${ }^{63}$ Mirzeoff, Jak zobaczyć świat?, s. 48.

${ }^{64}$ Ideę prywatności smartfona można zakwestionować, bo chociaż to najbardziej intymny gadżet, to treści w nim zawarte w dużym stopniu są publiczne.

${ }_{65}$ M. Maida, Selfportrait with Webcam [online], <http://klammer.mur.at/texte/pdf/ katalogtext_josef_klammer_webcam_de_engl.pdf> [dostęp: 30 stycznia 2017]. 
Z tego też względu Edgar Gómez Cruz i Helena Thornham w proponowanej interpretacji społecznych praktyk selfie odrzucają powiązania obrazu $z$ wielką tradycją zachodnioeuropejskiego autoportretu. Piszą:

Po pierwsze, należy usytuować żądania uprawomocnienia [dyskursu selfie], nie w ramach subiektywności czy intymnych relacji z obrazem, lecz w ramach szerszego dyskursu nowych mediów i konsumeryzmu, gdzie indywidualizm, intencjonalność i racjonalna przyczynowość są domyślnymi typami ekspresji ${ }^{66}$.

Zatem powinniśmy rozważać selfie na tle procesów społecznych, kulturowych i ekonomicznych ${ }^{67}$.

O liczbie selfie krążących w sieci świadczy głośny projekt realizowany przez Lva Manovicha i jego zespół w roku 2014. Selfiecity pozwala na zestawienie danych dostarczanych przez osoby umieszczające swój portret w serwisie Flickr oraz ich analizę za pomocą narzędzi do analizowania wielkich zbiorów danych. Jak pisze Ewa Wójtowicz, przedmiotem analizy było 3200 zdjęć z pięciu miast, celem - odnalezienie wzorców i podobieństw ${ }^{68}$. Wyniki analizy obejmowały statystyki tego, kto częściej wykonuje selfie (kobiety), jaki jest procent uśmiechów, a jaki specyficznych póz. Czy te statystyki mówią nam coś o sposobie opowiadania życia przez współczesnych użytkowników Internetu? Jedną z najciekawszych informacji jest, w mojej opinii, ta, że wśród rozmaitych zdjęć umieszczanych w serwisie, tylko 4 proc. stanowią selfie. Reszta to zdjęcia potraw, kotów, psów, samochodów, domów, stóp na tle miejsc codziennych i turystycznych, i wszelkich innych tematów (i kotów).

Z perspektywy pamięci autobiograficznej selfie jest jedynie cząstką gigantycznej wizualnej autobiografii, pisanej wspomnieniami rzeczy, osób czy niedoskonale (bo tylko wizualnie) notowanych smaków potraw. Czy jednak po latach będzie można do nich sięgnąć, jak czynili cierpiący na demencję pensjonariusze domu opieki w holenderskim Borger?

Najważniejszą cechą selfie jest to, że wykonywane jest smartfonem (we wcześniejszych wersjach - telefonem komórkowym), a więc przedmiotem, który zawsze jest pod ręką. Można więc dokumentować potencjalnie

${ }^{66}$ E. Gómez Cruz, H. Thornham, Selfies beyond self-representation: the (theoretical) $f(r)$ ictions of a practice, "Journal of Aesthetics \& Culture" [online] 2015, 7, <http://dx.doi. org.mev3k2ps00a1.han.amu.edu.p1/10.3402/jac.v7.28073> [dostęp: 30 stycznia 2017].

${ }^{67} \mathrm{~W}$ tym świetle na przywoływany wcześniej przykład wystawy w Saatchi spojrzeć należy inaczej i uwzględnić, że jest ona połączona z promocją producenta telefonów Huawei, którego przedstawiciele wypowiadają się w materiałach promocyjnych, Saatchi gallery to explore...

${ }^{68}$ E. Wójtowicz, Sztuka w kulturze postmedialnej, Gdańsk 2016, s. 187. 
w ka ż dej sytuacji (selfie z pogrzebu Mandeli pokazuje, że smartfon zmienia także rozumienie granicy między sferą prywatną a tym, co społecznie uznawane jest za niestosowne). Jednak niewiele $z$ tej produkcji zostaje zachowane. Selfie znikają równie łatwo jak niegdyś fotografie papierowe, tylko w proporcjonalnie większej skali. Z obrazami cyfrowymi wiąże się sprzeczność - cenimy to, że są „lekkie”, że można szybko zastąpić jedno, uznane za nieudane, kolejnym, w danym momencie - lepszym. Nastawienie w stronę tej lekkości miał realizować Snapchat - fantastyczna wizja pozbywania się obrazów. Okazało się jednak, że użytkownicy chcą z jednej strony - pozbywać się obrazu, ale równocześnie nie mogą się z nim rozstać. Aplikację wzbogacono zatem w możliwość archiwizacji zrzutów ekranowych. Kolekcjonowanie śladów własnej aktywności w sieci odpowiada kompulsywnej potrzebie gromadzenia rzeczy, a także reprezentowanej przez selfie ekspresyjnej gadatliwości.

Przedstawiciel producenta smartfonów Glory Zhang mówi: „Pokolenie selfie staje się generacją autoekspresji, ponieważ każdy z nas pragnie eksplorować i dzielić z innymi naszą własną kreatywność za pomocą tego jednego narzędzia, do którego mamy dostęp: smartfonu" ${ }^{\prime 69}$. Czy jednak ten gigantyczny zbiór autobiografii nie sprawia, że, paradoksalnie, coraz łatwiej zapominamy, miast pamiętać? Użytkownicy portali społecznościowych nieustannie tkają opowieści o sobie, pokazują, co jedzą, co robi ich kot, kogo spotykają. Chcą podzielić się każdym przeżyciem, każdym doświadczeniem. Nieraz można dostrzec w przestrzeni publicznej grupki skupione wokół świecących ekranów smartfonów, dzielących się zdjęciami, memami, filmami ${ }^{70}$. Czy jednak w masie tych autobiografii mają jeszcze $z$ kim się nimi dzielić? Czy inni słuchają ich opowieści, czy też tylko chcą opowiedzieć własne? Może sam akt działania autobiograficznego ma na celu jedynie utwierdzenie nas samych $\mathrm{w}$ przekonaniu o własnym istnieniu?

\section{KONKLUZJA: PAMIĘĆ AUTOBIOGRAFICZNA JAKO NADPISYWANIE}

Raz do roku z cyfrowych zdjęć zapisanych w pamięci mojego komputera składam jeden album pokazujący miejsca, które w tym czasie zwiedziłam. Zwykle znajduję na to czas dopiero kilka miesięcy po powrocie, zatem muszę

69 Saatchi gallery to explore...

${ }^{70}$ Równie często widzimy twarze osób samotnie pochłoniętych interakcją w telefonie, co wskazywałoby na konieczność pogłębionej refleksji nad proksemiką zapośredniczonych relacji. Piszą o tym m.in. Mikko Villi i Matteo Stochetti. Zob. M. Villi, M. Stochetti, Visual mobile communication, mediated presence and the politics of space, "Visual Studies” 2011, 26(2), s. 102-112. 
cofnąć się pamięcią i zaktualizować swoje wspomnienia, przypomnieć sobie nazwy miast i daty. Następnie drukuję album $\mathrm{w}$ formie papierowej książki. Z setek fotografii wybieram te, które uznaję za najlepsze. Z jednej zatem strony boję się utraty wspomnień (i awarii dysku zawierającego pliki), ale nie widzę potrzeby, by drukować wszystko. Kiedy oglądam albumy po czasie, paradoksalnie nie przypominam sobie widoków miejsc (zostały n a d pi s a ne wybranymi fotografiami), ale zapachy i dźwięki, które im towarzyszyły. Użyte przeze mnie czasowniki: cofnąć się, zaktualizować, nadpisać, znakomicie oddają istotę pracy pamięci autobiograficznej - jej procesualność.

Douwe Draaisma zauważa, że jednym z największych kulturowych mitów otaczających pamięć jest przekonanie, że chcielibyśmy pamiętać wszystko. W istocie jednak znakomicie zdajemy sobie sprawę z konieczności, ale też przywileju zapominania. W świecie cyfrowych obrazów logika pamiętania i zapominania zostaje przeniesiona na płaszczyznę materialnych realizacji. O sieci mówi się, że nic w niej nie ginie, zatem jesteśmy coraz bardziej narażeni na to, że część naszych wizerunków, zarejestrowanych przypadkowo (bo staliśmy się nieopatrznie "mistrzem drugiego planu” czyjegoś selfiel, wędruje po sieci bez naszej woli i wiedzy, poza naszą pamięcią. Z drugiej strony, nadal często nie mamy tych obrazów, które wyznaczają ważne momenty naszego życia.

Popularność selfie, techniki time lapse, foto- i wideoblogów, i licznych innych form kreowania wizualnej opowieści autobiograficznej idzie w parze z praktykami niewizualnymi. Przeglądając ofertę internetowych i stacjonarnych księgarni można się przekonać, że znaczną część produkcji literackiej stanowią książki biograficzne i autobiograficzne (chociaż przecież zarówno pisanie dzienników, jak i - realizująca potrzebę komunikacji z innymi - sztuka epistolarna nie są wynalazkiem dzisiejszym). Wszystkie one wskazują na wzrost znaczenia narracji biograficznej w kulturze współczesnej. Przywołane w tekście przykłady z różnych dziedzin kultury audiowizualnej jednoznacznie wskazują, że technologiczne, pozornie trwałe i niezmienne rejestracje przeszłości są mediowane zarówno procesami zachodzącymi w naszym umyśle poza naszą świadomością, jak i świadomie, za pomocą dostępnych środków technicznych. Tym samym jednak zasadniczo zmienia się relacja przeszłości do teraźniejszości, postrzeganej przez pryzmat technologii wizualnych. Mediowanie wspomnień m.in. przez fotografię sprawia, że ostatecznie nie możemy uważać obrazu za źródło wiedzy o zdarzeniach (co zresztą przeczuwali już badacze wizualni w wieku XX). Raczej można by powiedzieć: przeszłość zapisana na zdjęciach jest nieustannie dostępna i staje się częścią teraźniejszości. Obrazy fotograficzne są zatem nie tyle „kotwicami” dla pamięci, ile by pozostać przy morskiej metaforyce - dryfującymi łodziami, wypełnionymi wspomnieniami i zderzającymi się z łodziami innych. 
Marianna Michałowska

Instytut Kulturoznawstwa

Uniwersytet im. Adama Mickiewicza w Poznaniu

\section{AUTOBIOGRAPHICAL MEMORY IN DIGITAL TIMES}

\section{Summary}

The analysis of everyday practices focused on photography has always been an important element of the theoretical reflection on the media. Such a social approach can be found in the writings of classics, such as Benjamin, Sontag, Barthes, and Berger, as well as contemporary theorists. In their works one can find reflection on the cultural need to create one's image both for oneself and for others. In theory, this problem has been formulated in different ways. It may refer to making a family album (Hirsch) or to the selfie as an "extension and enhancement of a long tradition of the self-portrait" (Mirzeoff) or to action that embodies an imagined identity, rooted in communication practices (van Dijck). The gist of those discussions is the perception of oneself and others, and the technological methods of picturing, experiencing, and distributing that perception in society. The paper presents an analysis of the evolution of cultural meanings attributed to the autobiographical memory that affects the concept of identity. Photobiographies can be placed between two extremes: the nineteenth-century belief that "photography cannot flatter," remembered by Douve Draaisma, and contemporary picture-editing programs. José van Dijck argues that contemporary digital pictures are usually "living" since they can be endlessly modified. The paper has been divided into two parts. One is a short survey of qualitative methods, based on photography and the idea of the autobiographical memory. The other presents biographical artistic practices of Krzysztof Pruszkowski, Nancy Burson, Marek Lalko, and Josef Klammer, as well as autobiographical Internet production (e.g., selfie and time-lapse photography). The conclusion is that the digital media have changed the status of the autobiographical memory by mediatizing its presence in reality.

Keywords:

autobiographical memory, narrative identity, photography, selfie, time lapse 